\title{
Coupled Northern Hemisphere permafrost-ice-sheet evolution over the last glacial cycle
}

\author{
M. Willeit and A. Ganopolski \\ Potsdam Institute for Climate Impact Research (PIK), Potsdam, Germany \\ Correspondence to: M. Willeit (willeit@ pik-potsdam.de)
}

Received: 21 January 2015 - Published in Clim. Past Discuss.: 27 February 2015

Revised: 29 June 2015 - Accepted: 1 September 2015 - Published: 18 September 2015

\begin{abstract}
Permafrost influences a number of processes which are relevant for local and global climate. For example, it is well known that permafrost plays an important role in global carbon and methane cycles. Less is known about the interaction between permafrost and ice sheets. In this study a permafrost module is included in the Earth system model CLIMBER-2, and the coupled Northern Hemisphere (NH) permafrost-ice-sheet evolution over the last glacial cycle is explored.

The model performs generally well at reproducing present-day permafrost extent and thickness. Modeled permafrost thickness is sensitive to the values of ground porosity, thermal conductivity and geothermal heat flux. Permafrost extent at the Last Glacial Maximum (LGM) agrees well with reconstructions and previous modeling estimates.

Present-day permafrost thickness is far from equilibrium over deep permafrost regions. Over central Siberia and the Arctic Archipelago permafrost is presently up to $200-500 \mathrm{~m}$ thicker than it would be at equilibrium. In these areas, present-day permafrost depth strongly depends on the past climate history and simulations indicate that deep permafrost has a memory of surface temperature variations going back to at least $800 \mathrm{ka}$.

Over the last glacial cycle permafrost has a relatively modest impact on simulated NH ice sheet volume except at LGM, when including permafrost increases ice volume by about $15 \mathrm{~m}$ sea level equivalent in our model. This is explained by a delayed melting of the ice base from below by the geothermal heat flux when the ice sheet sits on a porous sediment layer and permafrost has to be melted first. Permafrost affects ice sheet dynamics only when ice extends over areas covered by thick sediments, which is the case at LGM.
\end{abstract}

\section{Introduction}

The existence and thickness of permafrost is a result of the history of energy balance at the Earth's surface and the deep Earth heat flow. Assuming that the geothermal heat flow did not notably change over the Quaternary, the present permafrost state has been shaped mainly by past surface ground temperature variations (Osterkamp and Gosink, 1991). The formation time of deep permafrost can take several 100000 years, and it is therefore possible that some, perhaps most, of current permafrost had its origin at the beginning of the Pleistocene era (Lunardini, 1995).

Also, previous glaciation periods have played an important role in the evolution of permafrost. Thick ice sheets have a strong insulation effect on the ground below and effectively decouple the ground temperature from the air temperature over the ice. Below ice sheets permafrost can be melted from below by the geothermal heat flux. So, previously glaciated regions will show a lesser volume of frozen ground than unglaciated regions with similar climatic histories. In this regard it is important that Canada was heavily glaciated while most of Siberia had remained ice-free during the past glacial cycle. Thus, the present permafrost thickness in Siberia is much greater than in Canada, even though the climates are similar.

Not only is permafrost affected by ice sheets, but it can potentially also affect ice sheet dynamics by influencing the basal conditions of the ice sheets. Basal sliding requires the base of the ice sheet to be at pressure melting point. This allows ice to melt at the base and to form a water layer which facilitates sliding of the ice sheet by partly decoupling it from the ground below (e.g., Hooke, 2005).

Several studies have investigated the subglacial conditions of the Laurentide ice sheet (LIS) during the last glacial cy- 
cle. Marshall and Clark (2002) suggested that at the Last Glacial Maximum (LGM) $20-40 \%$ of the LIS was warmbased but the value increased to $50-80 \%$ during glacial termination. Tarasov and Peltier (2007) obtained a warm-based fraction of around 50\% at LGM. Ganopolski et al. (2010) found a temperate base fraction of around $20 \%$ throughout most of glacial periods with only a minor increase during deglaciation. Studies including the effect of permafrost on bedrock thermodynamics found a small effect of permafrost on the melted base fraction of the LIS (Bauder et al., 2005; Tarasov and Peltier, 2007), although the absolute values of warm-based ice fraction are very different between the two studies. Bauder et al. (2005) simulated a slightly increased ice thickness on the southern flank of the LIS due to the inclusion of permafrost because of a slower subsurface warming. The effect of permafrost on ice sheet evolution emerging from these studies remains therefore debatable, and additional analyses are required to clarify its importance.

The main limitation for long-term permafrost evolution evaluation is the lack of coupled models including a permafrost component that are capable of performing multimillennial transient simulations. All modeling studies on the long-term evolution of permafrost have been performed by somehow prescribing surface temperature changes as a boundary condition and ignoring the various permafrost feedbacks on climate. Even this simplified offline modeling approach is problematic because of the limited climate modeling available on the glacial cycles timescale. As a workaround, Tarasov and Peltier (2007) used temperature forcing inferred from interpolated LGM and preindustrial climate model simulations to explore the permafrost evolution over the last glacial cycle. A step forward in this respect was done by Kitover et al. (2013), who used surface air temperature from transient simulations with an Earth system model of intermediate complexity (EMIC) to estimate the permafrost thickness evolution during the last $21 \mathrm{kyr}$ at selected locations in Eurasia using the VAMPER model. However, the boundary condition actually needed for the solution of the vertical temperature profile in the ground is the mean annual ground surface temperature (MAGST). The derivation of MAGST from annual surface air temperature is not straightforward, mainly because of the crucial role played by snow cover in insulating the ground from the air above (Smith and Riseborough, 2002). An explicit representation of the ground surface temperature is therefore desirable to realistically model the permafrost evolution. A newer version of VAMPER now explicitly considers also the effect of snow cover (Kitover et al., 2015).

In this study a permafrost module is implemented into the coupled climate-ice-sheet model CLIMBER-2. Ground surface temperature is modeled explicitly. This updated version of CLIMBER-2 allows for the first time the estimation of permafrost evolution during the last glacial cycle and beyond over the whole Northern Hemisphere with a model forced only by atmospheric $\mathrm{CO}_{2}$ concentrations and variations in orbital configuration. It enables the assessment of the relevance of permafrost-ice-sheet interactions in a fully coupled setup.

Recently, a permafrost module has been included in CLIMBER-2 (Crichton et al., 2014). It was introduced for the purpose of an improved representation of the land carbon cycle. The permafrost module discussed in the present paper considers only the physical processes in the ground extending to a depth of $5 \mathrm{~km}$. It is implemented at a much higher spatial resolution than the original CLIMBER-2 land surface scheme, and it is coupled to an ice sheet model. It can therefore be regarded as complementary to the CLIMBER-2 developments described in Crichton et al. (2014).

Given the very long characteristic timescales of deep permafrost evolution, the importance of model initialization is a relevant issue that has not received proper attention in the past. The dependence of present permafrost state on the initial conditions is also explored in this paper.

\section{Methods}

\subsection{Model description}

A newly developed permafrost module has been integrated into the CLIMBER-2 Earth system model of intermediate complexity (Brovkin et al., 2002; Ganopolski et al., 2001; Petoukhov et al., 2000). CLIMBER-2 includes the 3-D polythermal ice sheet model SICOPOLIS (Greve, 1997), which is applied only to the Northern Hemisphere. The climate and ice sheet components are coupled via a physically based surface energy and mass balance interface (Calov et al., 2005). CLIMBER-2 has already successfully simulated the past glacial cycles (Ganopolski et al., 2010; Ganopolski and Calov, 2011).

Up to now in CLIMBER-2 the geothermal heat flux was applied directly at the base of the ice sheets (Calov et al., 2005). This approach neglects the thermal inertia of the ground and the history of the temperature profile below the ice, which could potentially affect ice sheet dynamics. To realistically represent ground heat transfer a proper treatment of phase changes of water is essential. This requires the implementation of a permafrost module, which is described next.

The 3-D temperature field in the ground is computed assuming that vertical heat transfer occurs only through conduction and that horizontal heat fluxes can be ignored. With these assumptions the vertical profile of temperature $(T)$ in the ground is described by a 1-D diffusion equation with phase change of water (Carslaw and Jaeger, 1959):

$\rho C \frac{\partial T}{\partial t}=\frac{\partial}{\partial z}\left(k \frac{\partial T}{\partial z}\right)-L_{\mathrm{f}} \rho_{\mathrm{w}} \frac{\partial \theta_{\mathrm{w}}}{\partial t}$,

where $\rho, C$ and $k$ are bulk values of the ground density, specific heat capacity and thermal conductivity, respectively. $L_{\mathrm{f}}$ is the latent heat of fusion of water, $\rho_{\mathrm{w}}$ the density of water 
and $\theta_{\mathrm{w}}$ the volumetric water content. $z$ is the vertical coordinate and $t$ is time.

Similarly to Tarasov and Peltier (2007) the model discriminates between rock and sediments based on the presentday sediment thickness estimates from Laske and Masters (1997). Areas where sediments are shallower than $10 \mathrm{~m}$ are assumed to be sediment-free. Rock is assumed to be nonporous, while sediments are characterized by depthdependent porosity $(\phi)$. Porosity in sediments is determined by the value of porosity at the surface and decreases exponentially with depth according to Athy (1930) and Kominz et al. (2011):

$\phi(z)=\phi_{\mathrm{sur}} e^{-\frac{z}{\phi_{p}}}$.

$\phi_{\text {sur }}$ is the surface porosity and $\phi_{p}$ determines the scale of the exponential decrease. Sediments are assumed to be saturated with water. Empirical evidence suggests that pore water in the ground generally does not freeze at the freezing point of pure water $\left(0^{\circ} \mathrm{C}\right.$ at standard atmospheric pressure $)$, but rather at lower temperatures. The highest temperature $\left(T_{\mathrm{m}}\right)$ at which ice could exist in the ground in a given circumstance specifies the freezing point depression of water in the ground (e.g., Hillel, 2012). The freezing point depression is induced by adsorption forces, capillarity and ground heterogeneity (Williams and Smith, 1989). It is further depressed if the water includes solutes (e.g., Watanabe and Mizoguchi, 2002; Niu and Yang, 2006) or if pore water pressure is increased. However, not all water in the ground freezes at this temperature. Lowering the temperature causes more and more water to change to ice and this gradual change can be described by an unfrozen water fraction function, $f_{\mathrm{w}}$ (Lunardini, 1988). $f_{\mathrm{w}}$ is generally assumed to be a continuous function of temperature in a specified range. There are many approximations to $f_{\mathrm{w}}$ in the fully saturated ground (e.g., Galushkin, 1997; Lunardini, 1988). Similarly to Kitover et al. (2013) we use the exponential function proposed by Mottaghy and Rath (2006):

$f_{\mathrm{w}}\left(T, T_{\mathrm{m}}\right)= \begin{cases}e^{-\left(\frac{T-T_{\mathrm{m}}}{\Delta T_{\mathrm{w} / \mathrm{i}}}\right)^{2}} & T<T_{\mathrm{m}} \\ 1 & T \geq T_{\mathrm{m}} .\end{cases}$

All water in the ground is therefore in a liquid state at temperatures higher than $T_{\mathrm{m}}$ and almost all water is frozen at temperatures below $T_{\mathrm{m}}-2 \Delta T_{\mathrm{w} / \mathrm{i}}$. In between these two values water and ice coexist.

We define a grid box to be permafrost if at least half of the water is frozen, which formally translates into a condition on temperature: $T \leq T_{\mathrm{m}}-0.83 \Delta T_{\mathrm{w} / \mathrm{i}}$. For our purpose the relevance of permafrost lies in the latent heat related to phase changes of water and therefore this definition seems the most appropriate. This temperature condition on the existence of permafrost is applied also to rock, although rock is assumed to be nonporous and therefore contains no water. Since rock is always water-free in the model and thus no phase changes can occur, the presence of permafrost in rock does not affect heat conduction and just indicates that the temperature conditions would potentially be favorable for water, if present, to freeze. In other models, permafrost is defined by the $-1{ }^{\circ} \mathrm{C}$ isotherm (Kitover et al., 2013; Osterkamp and Gosink, 1991) or by the melting point temperature (Tarasov and Peltier, 2007).

The freezing/melting point temperature $T_{\mathrm{m}}$ depends on the pore water pressure. We assume that the water in the ground is in hydrostatic equilibrium and therefore the pressure increases linearly with depth $\left(p=-\rho_{\mathrm{w}} g z\right)$ (Tarasov and Peltier, 2007). Additionally, when the surface is covered by an ice sheet, we assume that the pore water is affected by the additional pressure of the ice loading. This is justified by the large areal extent of the loading (ice sheets cover large areas) and by the saturated ground which inhibits a dissipation of the additional pressure through water drainage. Since the thickness of the ice sheets is variable in time, also $T_{\mathrm{m}}$ will in general be time-dependent. Since water and ice density differ only slightly, hydrostatic pressure in ice or water at a given depth is similar and we therefore assume that the pressure melting point $T_{\mathrm{m}}$ decreases linearly from the surface of the ice sheet down to the $5 \mathrm{~km}$ depth below the ice sheet base with a gradient of $8.7 \times 10^{-4} \mathrm{Km}^{-1}$ (e.g., Hooke, 2005).

As the ground is considered to be saturated, the following relations apply:

$\theta_{\mathrm{w}}=\phi f_{\mathrm{w}}$, volumetric water content

$\theta_{\mathrm{i}}=\phi-\theta_{\mathrm{w}}$, volumetric ice content.

The volumetric heat capacity $\rho C$ for sediments is computed as a weighted mean of the different constituents:

$\rho C=(1-\phi) \rho_{\mathrm{s}} C_{\mathrm{s}}+\theta_{\mathrm{w}} \rho_{\mathrm{w}} C_{\mathrm{w}}+\theta_{\mathrm{i}} \rho_{\mathrm{i}} C_{\mathrm{i}}$,

while for rock it is

$\rho C=\rho_{\mathrm{r}} C_{\mathrm{r}}$.

$\rho_{\mathrm{S}}, \rho_{\mathrm{r}}$ and $\rho_{\mathrm{i}}$ are the densities of sediments, rock and ice and $C_{\mathrm{s}}, C_{\mathrm{r}}, C_{\mathrm{w}}$ and $C_{\mathrm{i}}$ are the specific heat capacities of sediments, rock, liquid water and ice. The effective thermal conductivity of the groundwater-ice mixture is calculated following Farouki (1981):

$k=k_{\mathrm{s}}^{1-\phi} k_{\mathrm{w}}^{\theta_{\mathrm{w}}} k_{\mathrm{i}}^{\theta_{\mathrm{i}}}$

The values used for all parameters entering the previous equations are listed in Table 1 . For parameters which are included in the sensitivity analysis the range of values used is also indicated together with the reference values.

Equation (1) is solved at each point on the ice-sheet grid ( $1.5^{\circ}$ resolution in longitude and $0.75^{\circ}$ in latitude) down to a depth of $5 \mathrm{~km}$ using an implicit scheme with an annual time step. The ground is discretized in 30 layers. In order to increase the vertical resolution close to the surface, the 
Table 1. Parameter description and values. Parameters where more than one value is listed are used in the sensitivity study. Bold values indicate the reference values.

\begin{tabular}{lll}
\hline Parameter & Description & Value(s) \\
\hline$\rho_{\mathrm{s}}, \rho_{\mathrm{r}}$ & Sediments/rock density & $2700 \mathrm{~kg} \mathrm{~m}^{-3}$ \\
$\rho_{\mathrm{W}}$ & Water density & $1000 \mathrm{~kg} \mathrm{~m}^{-3}$ \\
$\rho_{\mathrm{i}}$ & Ice density & $910 \mathrm{~kg} \mathrm{~m}^{-3}$ \\
$C_{\mathrm{S}}, C_{\mathrm{r}}$ & Sediments/rock-specific heat capacity & $800 \mathrm{~J} \mathrm{~kg}^{-1} \mathrm{~K}^{-1}$ \\
$C_{\mathrm{W}}$ & Water-specific heat capacity & $4200 \mathrm{~J} \mathrm{~kg}^{-1} \mathrm{~K}^{-1}$ \\
$C_{\mathrm{i}}$ & Ice-specific heat capacity & Temperature-dependent \\
$k_{\mathrm{S}}, k_{\mathrm{r}}$ & Sediments/rock thermal conductivity & $2, \mathbf{3}, 4 \mathrm{~W} \mathrm{~m}^{-1} \mathrm{~K}^{-1}$ \\
$k_{\mathrm{W}}$ & Water thermal conductivity & $0.58 \mathrm{~W} \mathrm{~m}-1 \mathrm{~K}^{-1}$ \\
$k_{\mathrm{i}}$ & Ice thermal conductivity & Temperature-dependent \\
$L_{\mathrm{f}}$ & Latent heat of fusion for water & $3.35 \times 10^{5} \mathrm{~J} \mathrm{~kg}^{-1}$ \\
$\phi_{\mathrm{sur}}$ & Surface porosity & $0.0,0.25, \mathbf{0 . 5}, 0.75 \mathrm{~m}^{3} \mathrm{~m}$ \\
$\phi_{\mathrm{p}}$ & Scale of decrease of porosity with depth & $500, \mathbf{1 0 0 0}, 2000 \mathrm{~m}$ \\
$\Delta T_{\mathrm{w} / \mathrm{i}}$ & Width of freezing/thawing temperature interval & $1, \mathbf{2}, 3 \mathrm{~K}$ \\
\hline
\end{tabular}

spacing between levels increases exponentially with depth. The top ground layer is $0.3 \mathrm{~m}$ thick. A sensitivity analysis showed that 30 vertical layers are necessary to properly represent the vertical temperature profile. When the number of layers decreases below 20, results start to differ considerably, while an increase in the vertical resolution results in negligible changes. More details on the solution of Eq. (1) are given in Appendix A.

The lower boundary condition for the 1-D diffusion equation is given by a constant in time but spatially varying geothermal heat flux applied at $5 \mathrm{~km}$ depth. Two alternative data sets of geothermal heat flux are implemented (Fig. 2). The first one is based on data from Pollack et al. (1993), modified as described in Calov et al. (2005) and used in CLIMBER-2 in all previous studies, and the second one is the more recent global data set from Davies (2013).

At the surface, over ice-free land, the computed MAGST is prescribed as a boundary condition. The computation of the MAGST is based on the surface energy and mass balance interface (SEMI) described in Calov et al. (2005) and Ganopolski et al. (2010), extended to ice-free grid cells. When computing the surface energy balance, SEMI always assumes the existence of a virtual snow layer covering the surface. This assumption is relaxed and the energy balance calculation is extended to a surface covered by forest, grass or desert. The grid cell share of the three surface types, forest, grass and desert, is computed by the dynamic vegetation model VECODE (Brovkin et al., 1997), applied at the higher resolution of the ice sheet grid using the downscaled air temperature, positive degree days and precipitation. The surface energy balance is essentially computed in the same way as in the land surface scheme of the climate component but on the ice sheet model grid. Therefore, climatological fields which are needed for the computation of the energy fluxes are spatially bilinearly interpolated from the coarse grid of the atmospheric module to the fine grid of the ice sheet. These variables include air temperature, humidity, precipitation, downward shortwave and longwave radiation fluxes and wind speed. The orographic effect is taken into account by using simple vertical interpolations for temperature, wind and radiative fluxes, and by using additional parameterizations for precipitation (Calov et al., 2005). Compared to SEMI, the temperature of the snow layer and ground surface temperature are introduced as two additional prognostic variables, partly following HTESSEL (Dutra et al., 2010). When the surface is snow-covered the prognostic equation for snow temperature is

$$
\begin{aligned}
& c_{\mathrm{sn}} \frac{\partial T_{\mathrm{sn}}}{\partial t}=\mathrm{SW}^{\mathrm{net}}+\mathrm{LW}^{\downarrow}-\mathrm{LW}^{\uparrow}-H \\
& -\mathrm{LE}-\frac{k_{\mathrm{sn}}}{H_{\mathrm{sn}}}\left(T_{\mathrm{sn}}-T_{\mathrm{gs}}\right),
\end{aligned}
$$

where $T_{\mathrm{sn}}$ is the uniform temperature of the snow layer, $c_{\mathrm{sn}}$ the volumetric heat capacity of the snow layer and $T_{\mathrm{gs}}$ the ground surface temperature. The terms on the right represent net shortwave radiation absorbed at the snow surface, incoming and outgoing longwave radiation, sensible and latent heat flux and heat diffusion from the snow surface to the ground surface. $k_{\mathrm{sn}}$ is the heat conductivity of snow and $H_{\mathrm{sn}}$ is snow height. If the computed $T_{\mathrm{sn}}$ at the new time step is greater than $0^{\circ} \mathrm{C}$, the corresponding excessive energy is used to melt snow. The equation governing ground surface temperature is

$c_{\mathrm{g}} \frac{\partial T_{\mathrm{gs}}}{\partial t}=\frac{k_{\mathrm{sn}}}{H_{\mathrm{sn}}}\left(T_{\mathrm{sn}}-T_{\mathrm{gs}}\right)-\frac{k_{\mathrm{g}}}{h_{\mathrm{g}}}\left(T_{\mathrm{gs}}-\bar{T}_{\mathrm{gs}}\right)$.

The second term on the right represents heat diffusion toward the mean annual ground temperature $\bar{T}_{\mathrm{gs}}$ at depth $h_{\mathrm{g}}$. $k_{\mathrm{g}}$ is ground heat conductivity computed as in Eq. (8) and depends on surface porosity $\phi_{\text {sur }}$ and the frozen water fraction given by Eq. (3). The prognostic equation for snow water equivalent $\left(h_{\text {swe }}\right)$ is the same as in Calov et al. (2005). 


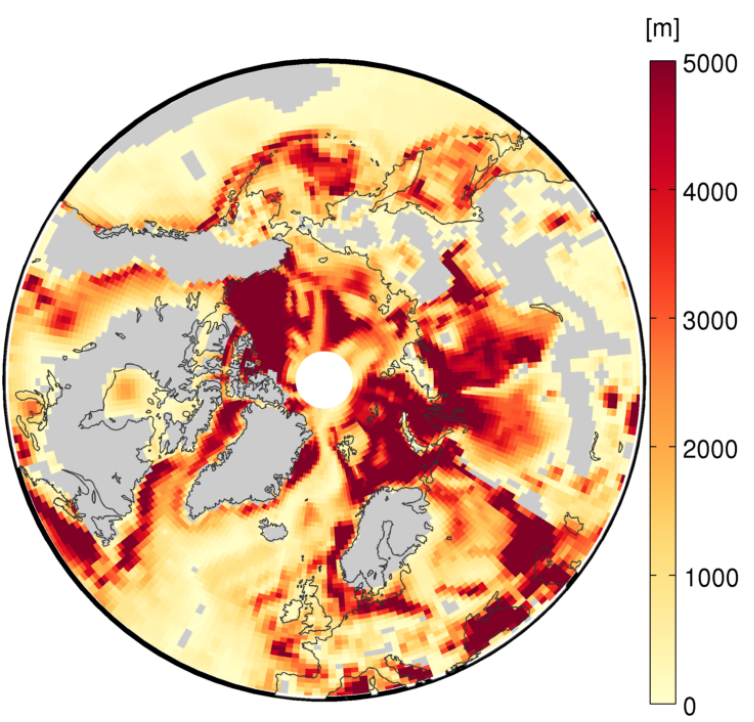

Figure 1. Sediment thickness and mask from Laske and Masters (1997). Grey shading indicates areas with sediment thickness lower than or equal to $10 \mathrm{~m}$, which are assumed to be sediment-free.

The prognostic equations are solved with a daily time step. A grid cell can be either snow-free, fully snow-covered or partly snow-covered. The grid cell fraction covered by snow $\left(f_{\mathrm{sn}}\right)$ is a function of snow height (Dutra et al., 2010):

$f_{\mathrm{sn}}=\min \left(1, \frac{H_{\mathrm{sn}}}{H_{\mathrm{sn}}^{\text {crit }}}\right)$,

where $H_{\mathrm{sn}}^{\text {crit }}=0.2 \mathrm{~m}$ is the critical snow height above which the whole grid is covered by snow. This is important for the stability of the numerical integration scheme, as it implies that the snow layer in a grid cell can never become smaller than $20 \mathrm{~cm}$ and very thin snow layers would require a very short integration time step. Snow height $\left(H_{\mathrm{sn}}[\mathrm{m}]\right)$ is related to the snow water equivalent $\left(h_{\text {swe }}\left[\mathrm{kg} \mathrm{m}^{-2}\right]\right)$ by

$H_{\mathrm{sn}}=\frac{h_{\mathrm{swe}}}{\rho_{\mathrm{sn}}} f_{\mathrm{sn}}$.

$\rho_{\mathrm{sn}}$ is snow density and is assumed to be constant with depth and to relax exponentially in time toward a maximum density as described in Verseghy (1991). Latent and sensible heat flux are computed separately for each surface type. Sensible heat flux is calculated using the bulk formula as in Eq. (7) in Calov et al. (2005) with the exchange coefficient depending on surface roughness. Latent heat flux is given by surface evaporation over bare ground and transpiration over grass and trees. Stomatal resistance depends on temperature, shortwave radiation, vapor pressure deficit and soil moisture following the linear formulation in Stewart (1988). No full hydrological cycle is implemented on the high-resolution grid, and the relative soil moisture $\left(r_{\text {soil }}\right)$ is roughly parameterized using precipitation $(P)$ and evapotranspiration (ET) from the

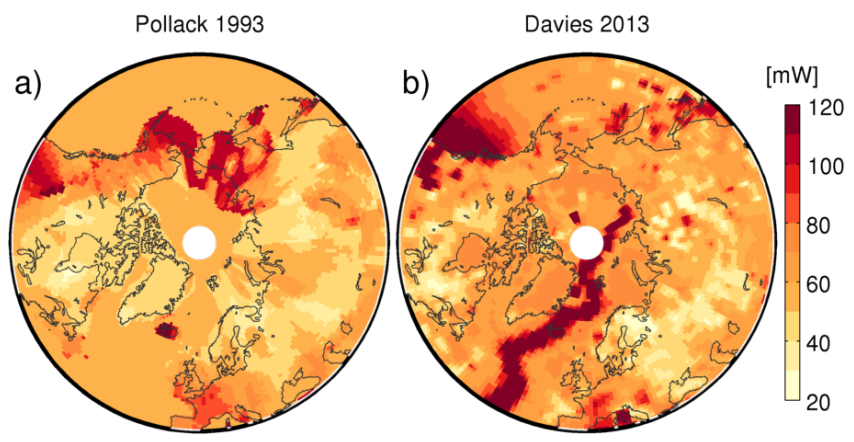

Figure 2. Geothermal heat flux from (a) Pollack et al. (1993) and (b) Davies (2013).

previous time step as

$r_{\text {soil }}= \begin{cases}0.8 & \frac{P}{\mathrm{ET}}>1 \\ \sqrt{\frac{P}{\mathrm{ET}}} & \frac{P}{\mathrm{ET}} \leq 1 .\end{cases}$

Longwave radiation is computed as in Calov et al. (2005). Surface albedo is a weighted average of snow-free albedo and snow albedo with the weighting factor depending on surface type. Seasonal freezing and thawing of the active layer close to the surface can cause a thermal offset between MAGST and top of permafrost temperature (TTOP) because of the different thermal conductivities of frozen and liquid water (Smith and Riseborough, 2002). TTOP can be between 0 and $2{ }^{\circ} \mathrm{C}$ lower than MAGST (Burn and Smith, 1988; Romanovsky and Osterkamp, 1995). The thermal offset is not accounted for in our model as it would require a detailed representation of the seasonally varying active layer, which is beyond the scope of this study focusing on permafrost evolution over much longer timescales.

If the ground surface is covered by water, e.g., by ocean or periglacial lakes, the top ground temperature is set to $0^{\circ} \mathrm{C}$. When the surface is overlaid by an ice sheet, the temperature profile in the ice sheet and the ground is solved simultaneously using a tridiagonal matrix algorithm, with the ice sheet surface temperature prescribed as top boundary condition. Ice sheet and ground are therefore fully two-way thermally coupled and the temperature at the ice sheet base is free to evolve in response to changes in ice surface temperature, internal ice sheet dynamics and ground heat flux.

\subsection{Experimental setup}

Different transient CLIMBER-2 simulations are used to estimate the permafrost evolution over the last glacial cycle and beyond. Orbital variations (Laskar et al., 2004) and the radiative forcing of greenhouse gases derived from the Antarctic ice cores (Ganopolski et al., 2010) are the only external forcings applied to the model. The radiative forcing by greenhouse gases includes the anthropogenic forcing over 


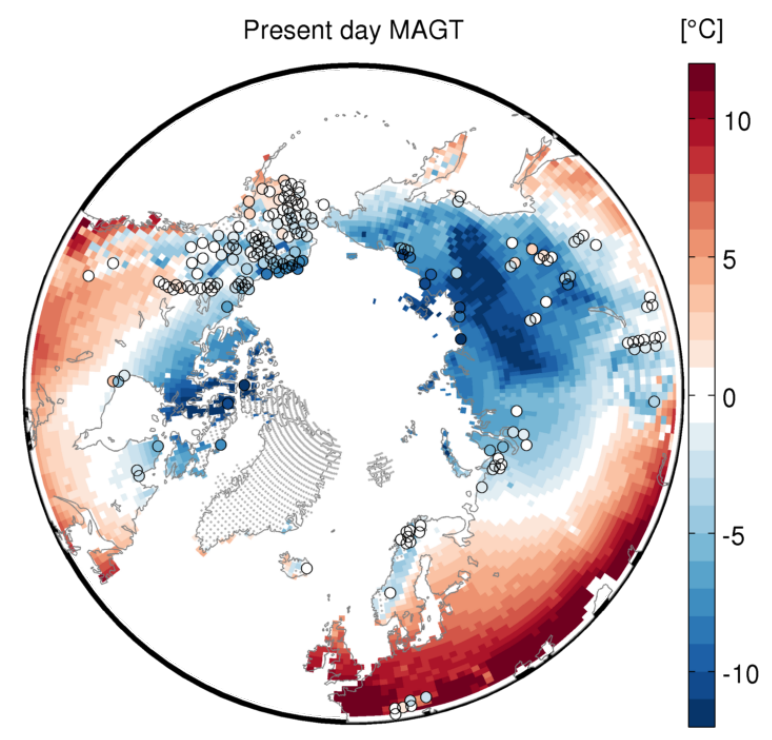

Figure 3. Comparison of present-day modeled mean annual ground temperature (MAGT) with site level observations from IPA (2010) and Romanovsky et al. (2010). Observations are represented by circles with the filling color showing temperature. Grey dots indicate grid cells where the model simulates present-day ice sheet cover.

the last centuries. The sediment thickness and mask are prescribed based on present-day estimates from Laske and Masters (1997) (Fig. 1). In all experiments, climate and ice sheets are initialized using preindustrial conditions. The initial 3$\mathrm{D}$ ground temperature field is in thermodynamic equilibrium with modeled preindustrial ground surface temperature and geothermal heat flux and considers also the effect of liquid and frozen water on thermal conductivity. The equilibrium temperature profiles over areas not covered by ice sheets can be estimated numerically without the need to run the whole climate-ice-sheet model to equilibrium (Appendix B).

A set of experiments is performed to assess the sensitivity of modeled permafrost extent and thickness to a number of poorly constrained parameters. These parameters include surface porosity $\phi_{\text {sur }}$, scale of decrease of porosity with depth $\phi_{\mathrm{p}}$, thermal conductivities of rock and dry sediments ( $k_{\mathrm{r}}$ and $k_{\mathrm{s}}$, respectively) and the width of the temperature range where water and ice coexist, $\Delta T_{\mathrm{w} / \mathrm{i}}$. The parameter values used in the ensemble are indicated in Table 1. Additionally, the model sensitivity to two different geothermal heat flux data sets is explored, i.e., Pollack et al. (1993) and Davies (2013). In this paper only uncertainties related to bed thermal parameters are assessed, but it is acknowledged that uncertainties in climate forcings are likely to be at least as important.

Given the long timescales involved in permafrost evolution, the present-day permafrost state has potentially a long memory of past climate variations. To explore the convergence of the simulated present permafrost state and permafrost evolution over the last glacial cycle, experiments are

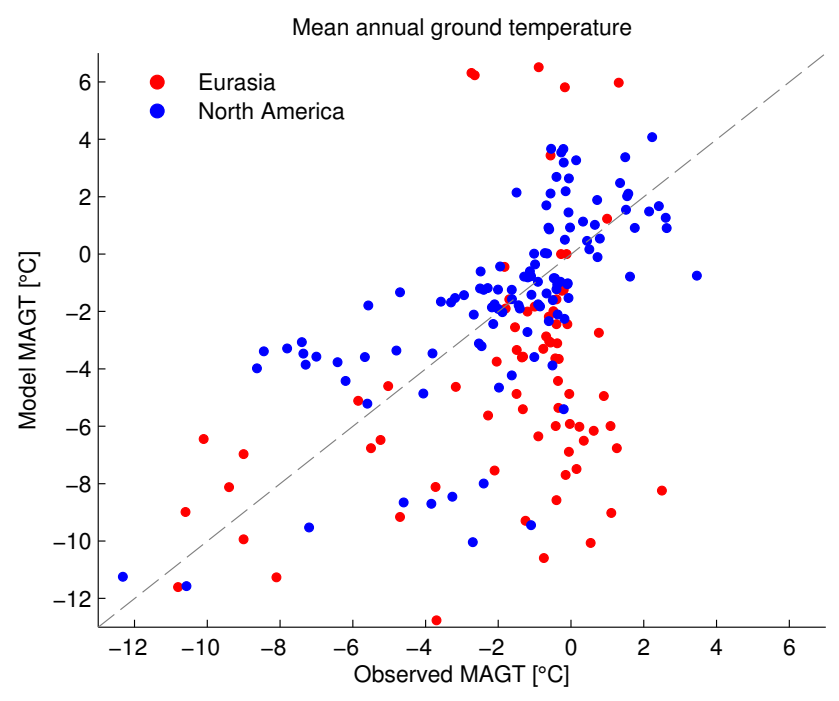

Figure 4. Scatter of modeled and observed present-day mean annual ground temperature (MAGT). Site level observations are from IPA (2010) and Romanovsky et al. (2010).

performed starting at interglacials progressively further back in time (i.e., MIS 5 (Eemian), 126; MIS 7, 240; MIS 9, 330; MIS 11, 405 and MIS 19, $780 \mathrm{ka})$.

\section{Results and discussion}

\subsection{Model performance for present day}

The modeled MAGST for present-day conditions is compared to site observations in Fig. 4. The model is generally able to reproduce the main patterns in MAGST except for southern Siberia, where the model underestimates the ground temperature by up to $5^{\circ} \mathrm{C}$. This is mainly caused by a $2-3^{\circ} \mathrm{C}$ cold bias in the simulated air temperature over this region and an underestimation of snow cover and thickness during winter. The reduced insulation by the thinner snow layer exposes the ground to the low air temperatures. In some other areas it is evident that the model resolution is not high enough to capture very local conditions, as for example in mountainous regions like the Alps.

The long timescales involved in deep permafrost buildup and the dependence of permafrost on surface temperature, and therefore also on ice sheet history, represent a challenge for model initialization. The present-day modeled permafrost used for model evaluation is the result of a transient climate-ice-sheet-permafrost model simulation over the past 780000 years. The dependence of the present-day permafrost state on model initialization is addressed in a later section.

The ability of the model to correctly simulate the area covered by permafrost rests mainly on a correct simulation of MAGST. A comparison of modeled permafrost area with continuous permafrost extent estimates indicates that per- 


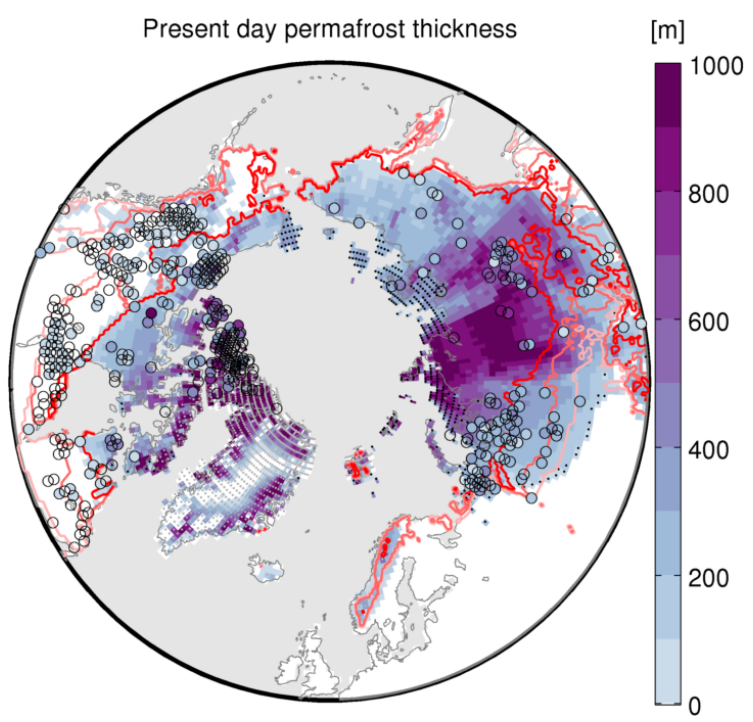

Figure 5. Comparison of modeled present-day permafrost thickness with estimates from boreholes. Permafrost thickness data for Canada are from Smith and Burgess (2004) and for Russia from Melnikov (1998). The modeled thickness is for the year AD 2000 from the reference model run. Observations are represented by circles with the filling color showing permafrost thickness. The red lines show the extent of continuous, discontinuous and isolated permafrost (from dark to light red) after Brown et al. (2014). Black dots indicate grid cells with relict permafrost and grey dots grid cells where the model simulates present-day ice sheet cover.

mafrost extent is generally well captured by the model, particularly over North America (Fig. 5). As expected given the negative temperature bias over central Eurasia, simulated permafrost extends too far south over southwestern Russia. The skill of the model at reproducing present-day permafrost extent is comparable to the skill of PMIP3 models (Saito et al., 2013).

Biases in MAGST have a major impact on permafrost thickness. This is evident in the overestimation of the permafrost thickness over parts of southern Siberia, where modeled ground temperatures are too low (Fig. 5). Permafrost thickness is also overestimated in the north of the Canadian Arctic Archipelago (Fig. 5). This is mainly a result of the low geothermal heat flux in the Pollack et al. (1993) data set in this region. Using the Davies (2013) geothermal heat flux, which has higher values over most of Canada (Fig. 2), remarkably reduces the tendency of the model to overestimate permafrost thickness over northern Canada (Fig. 6). Other deviations of modeled permafrost thickness from observations can be largely attributed to the use of globally uniform values of ground properties like thermal conductivity and porosity in the model. Permafrost thickness measurements from boreholes show a generally larger spatial variability than the modeled values reflecting the importance of local conditions, not resolved by the model. Explicitly introducing site-specific parameters in the model would probably

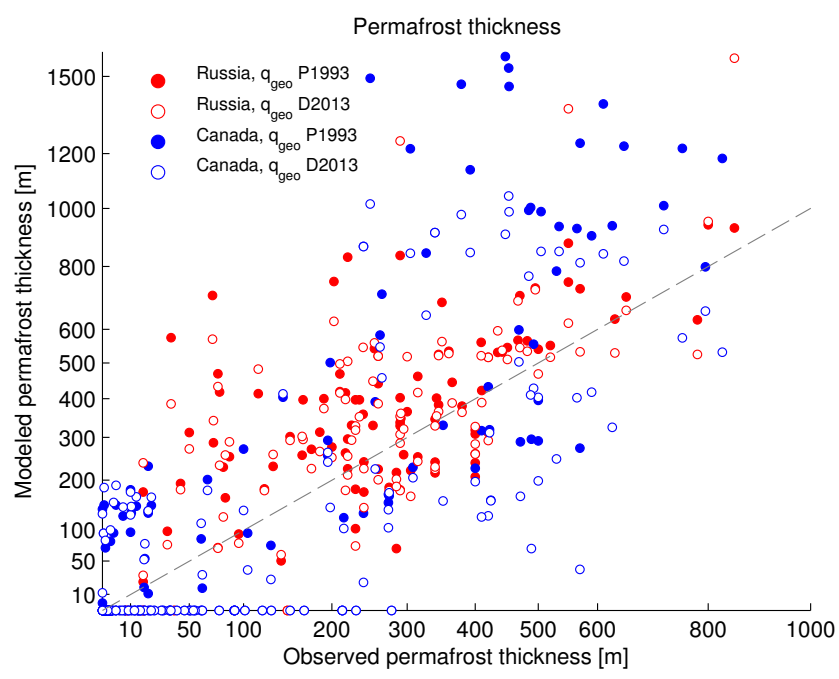

Figure 6. Scatter of modeled and observed permafrost thickness estimated from boreholes. Permafrost thickness data for Canada (blue) are from Smith and Burgess (2004) and for Siberia (red) from Melnikov (1998). Filled circles represent modeled permafrost thickness using the Pollack et al. (1993) and open circles using the Davies (2013) geothermal heat flux.

be necessary to improve the model skill at site level, but this is beyond the scope of this work. Despite these limitations the overall model performance for the present day is reasonably good (Figs. 5 and 6).

It has to be pointed out that permafrost thickness observations shown in Figs. 5 and 6 are determined using different methods. Some of the estimates are based on the depth of the $0^{\circ} \mathrm{C}$ isotherm, others on the base of ice-bearing permafrost. The freezing point depression due to pressure, chemical and ground particle effects can potentially introduce differences in thickness estimate of up to hundreds of meters between the two methods (Hardy and Associates, 1984). Observation data and model data should therefore be compared with caution.

\subsection{Sensitivity analysis}

Simulated permafrost thickness depends on the choice of uncertain parameter values. A sensitivity analysis is performed to quantify the relative importance of the various parameters. Higher ground porosity values (either higher $\phi_{\text {sur }}$ or higher $\phi_{\mathrm{p}}$ ) reduce the thickness of permafrost (Fig. 7a and b). A saturated ground with higher porosity can contain more water, which reduces the bulk thermal conductivity and therefore limits the diffusion of cold temperatures from the surface. At equilibrium, porosity affects permafrost thickness only by its effect on heat conductivity (Appendix B). In the transient evolution, the changes in heat capacity and latent heat effects also play an important role. Porosity has an impact mainly over Siberia, where it causes permafrost thickness 

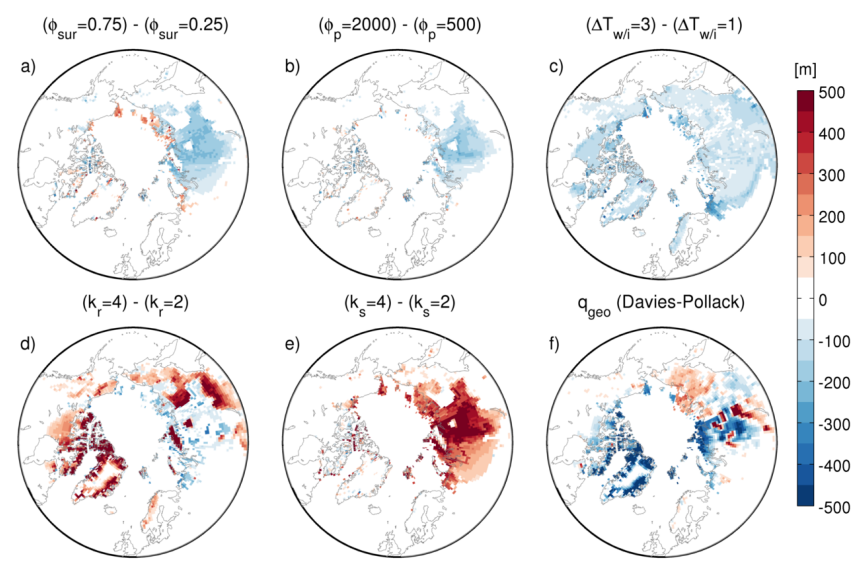

Figure 7. Sensitivity of present-day permafrost thickness to surface porosity (a), exponential decay scale of porosity with depth (b), temperature interval for ground freezing (c), rock (d) and dry sediments (e) thermal conductivity and geothermal heat flux (f).

differences of up to $100-200 \mathrm{~m}$. This is in quantitative agreement with the values reported in Kitover et al. (2013).

Heat conductivities of rock and sediments have a strong effect on modeled permafrost depth. In general, an increased conductivity in the top part of the ground layer favors the penetration of cold surface temperatures downward, causing a cooling and therefore a deepening of the permafrost layer. On the other hand, a higher conductivity of the bottom ground layer increases the temperature gradient due to the geothermal heat flux and consequently shallows the permafrost layer. These opposite effects are evident in Fig. 7d and e. Over regions covered by a thick sediment layer, like central Siberia (Fig. 1), an increase in sediment conductivity causes a deepening of the permafrost while over the same regions an increase of rock conductivity results in a shallower permafrost layer. Over regions with exposed nonporous bedrock, higher rock conductivity causes deeper permafrost to form (Fig. 7d).

Permafrost thickness is very sensitive to the applied geothermal heat flux. In fact, using two different geothermal heat flux databases (Davies, 2013; Pollack et al., 1993) (Fig. 2) changes the modeled permafrost thickness over most NH areas (Fig. 7f). Simulations with the Davies (2013) geothermal heat flux show systematically reduced permafrost depth over the Canadian Arctic Archipelago, Greenland and parts of central Siberia. In these regions the reduction in permafrost thickness is up to $300-400 \mathrm{~m}$. This can at least partly explain the overestimation of permafrost over the Canadian Arctic Archipelago in the reference run (Figs. 5 and 6), which uses the Pollack et al. (1993) data set.

The width of the temperature range where freezing occurs in the ground, $\Delta T_{\mathrm{w} / \mathrm{i}}$, has a minor impact on modeled permafrost thickness (Fig. 7c). Higher values of $\Delta T_{\mathrm{w} / \mathrm{i}}$ result in thinner permafrost, mainly because of the way permafrost is defined, which depends on $\Delta T_{\mathrm{w} / \mathrm{i}}$. Larger values of $\Delta T_{\mathrm{w} / \mathrm{i}} \mathrm{im}$ - ply that the water is freezing at lower temperature, therefore reducing the thickness of the layer with at least half the water frozen.

\subsection{Permafrost-ice-sheet evolution over the last glacial cycle}

As already shown in Ganopolski et al. (2010) and Ganopolski and Calov (2011) CLIMBER-2 realistically simulates the overall Northern Hemisphere ice volume variations over the last glacial cycles, as indicated by the reasonably good agreement of modeled and reconstructed sea level and benthic $\delta^{18} \mathrm{O}$. The model is also able to largely reproduce the ice sheet extent and thickness at LGM (Ganopolski et al., 2010). In Ganopolski et al. (2010) and Ganopolski and Calov (2011) the geothermal heat flux was applied directly at the base of the ice sheets, thus neglecting possible effects of the history of the bed temperature profiles. In the present study the geothermal heat flux is applied at $5 \mathrm{~km}$ depth and a fully interactive evolution of the bed temperature field is incorporated, including the effect of permafrost and the latent heat exchanges associated with phase change of water in the ground.

Applying the geothermal heat flux at $5 \mathrm{~km}$ depth but assuming uniform 3-D bed thermal properties (this is equivalent to setting porosity to zero) affects $\mathrm{NH}$ ice sheet volume only marginally (Fig. 8a). This justifies the approach used so far in CLIMBER-2 with geothermal heat flux applied directly below the ice sheets. A more detailed representation of the bed thermal properties, including a dependence of thermal conductivity and heat capacity on water and ice content, and accounting for the latent heat involved in phase changes of water, generally acts to increase the modeled ice volume. This is particularly evident at LGM, when ice sheet volume is higher by $15 \mathrm{~m}$ of sea level equivalent in the simulation including permafrost (Fig. 8a). The increase in ice volume is caused mainly by a thickening of the ice at the southern boundary of the LIS and Fennoscandian ice sheet (FIS) (Fig. 9a).

The reason for the relatively small effect of permafrost on ice sheet dynamics throughout most of the glacial cycle, except for LGM, can be found in the sediment thickness distribution over the continents. Over most of Canada and Scandinavia the sediment layer has been gradually thinned or almost completely removed by ice sheet erosion over the Pleistocene glacial cycles (Clark and Pollard, 1998; Melanson et al., 2013). As a result these areas are basically characterized by exposed nonporous bedrock. Therefore over these areas there is no difference in the ground heat conductivity between experiments with zero and nonzero porosity. However, when the ice sheets become large enough and expand into areas covered by thick sediment layers, the presence of water, ice and phase changes in the ground starts to play an important role. This is the case at LGM when the LIS and FIS spread into areas with sediments where a permafrost layer 


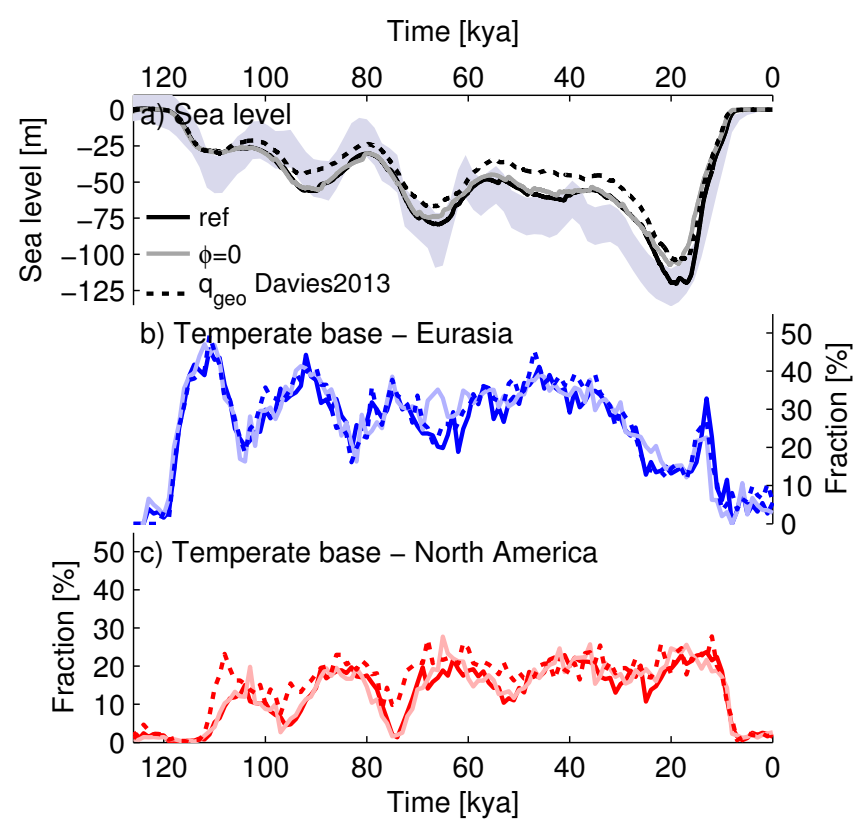

Figure 8. Evolution of (a) sea level and ice sheet temperate base area fraction over Eurasia (b) and North America (c) over the last glacial cycle. In all panels three model simulations are shown: the reference run (dark solid lines), the simulation with zero porosity representing the no permafrost case (light solid lines) and the model run with the geothermal heat flux from Davies (2013) (dotted lines). The modeled sea level is given by the modeled NH ice volume equivalent amplified by an additional $10 \%$ to roughly account for variations in Antarctic ice volume. The same approach was used in Ganopolski and Calov (2011) and is based on the estimates of Antarctic ice volume variations from Huybrechts (2002). The blue shading in (a) represents the sea level range from the reconstruction of Waelbroeck et al. (2002).

was formed previously to the arrival of the ice sheet. The ice sheet base can not be melted from below without first melting the permafrost layer. This introduces a delay in the ice base melting and the related increase in basal sliding and allows the ice sheet to grow thicker in these areas (Figs. 9a and 15a), in line with the findings of Bauder et al. (2005). The difference in ice sheet thickness is only marginally reflected in the fraction of ice sheet base which is at melting point (Fig. 8b and c), consistent with the results of Bauder et al. (2005) and Tarasov and Peltier (2007). As soon as the ice base becomes temperate the fast basal sliding causes a thinning and enhanced melting of the ice, which eventually reduces the total ice area and explains the small differences between temperate basal fractions in simulations with and without permafrost. The fraction of temperate basal area is generally larger for the FIS than for the LIS (Fig. 8b and c). For both ice sheets, the fraction is between 20 and $30 \%$ at LGM, remarkably less than estimated by Marshall and Clark (2002) and Tarasov and Peltier (2007) for the LIS. Part of the difference is due to the different initialization in the different studies.

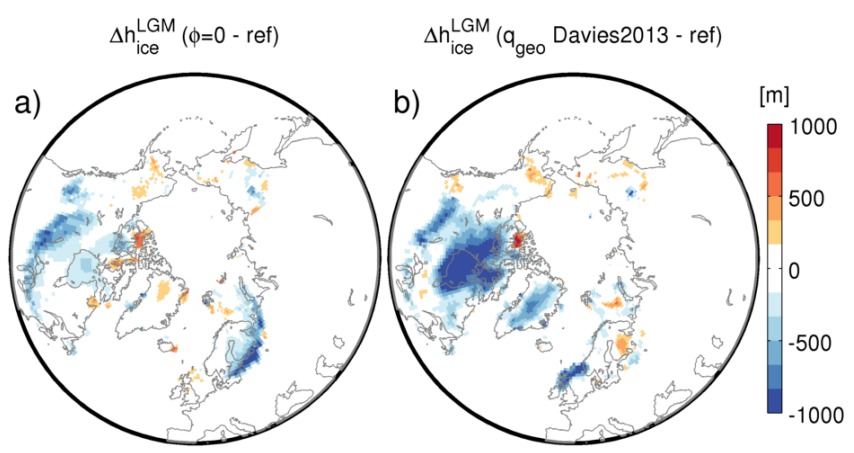

Figure 9. LGM (25-20 ka) ice thickness difference between (a) the reference run and the simulation with zero porosity and (b) the one with the geothermal heat flux from Davies (2013).

In the experiment initialized at $780 \mathrm{ka}$ the warm-based fraction is systematically $5-10 \%$ lower than in the experiment initialized at LGM (not shown). However, even accounting for the different initialization the fraction of warm-based LIS at LGM is still about $20 \%$ lower in our study compared to Tarasov and Peltier (2007). This difference can be attributed both to differences in climate forcing (first of all annual mean ice surface temperature) and ice sheet model formulation (in particular, the parameterization of basal sliding).

Using the more recent global estimates of the geothermal heat flux from Davies (2013) results in a lower modeled ice volume over the entire glacial cycle (Fig. 8a). The higher geothermal heat flux over northern Canada, the Hudson Bay and Greenland (Fig. 2) results in thinner ice over these regions (Fig. 9b). However, for the reasons outlined above, the fraction of temperate basal area is also not notably affected by the geothermal heat flux.

$\mathrm{NH}$ area of permafrost not covered by ice sheets and $\mathrm{NH}$ permafrost volume are strongly affected by ice sheets. Both area and volume are much larger over Eurasia than over North America (Fig. 10), and the time evolution is radically different over the two regions. While over Eurasia the area covered by ice sheets is small at any time compared to the total land area, a large fraction of North America is covered by ice sheet during most of the glacial cycle. As a consequence, permafrost area and volume more or less continuously increase from the Eemian to the LGM over Eurasia, but they strongly depend on the ice sheet evolution over North America (Fig. 10). North American permafrost area is controlled mainly by the ice sheet area and is to a good approximation anticorrelated with ice volume (Figs. 8a and 10b). North American permafrost volume is relatively constant throughout the last glacial cycle, except for lower values in the vicinity of the interglacials (Fig. 10d).

Present-day modeled NH permafrost area is around 15 million square kilometers, which is very close to the mode of the PMIP3 models (Saito et al., 2013). The empirical estimates of area of continuous permafrost are around 10 million square kilometers; including also the discontinuous per- 


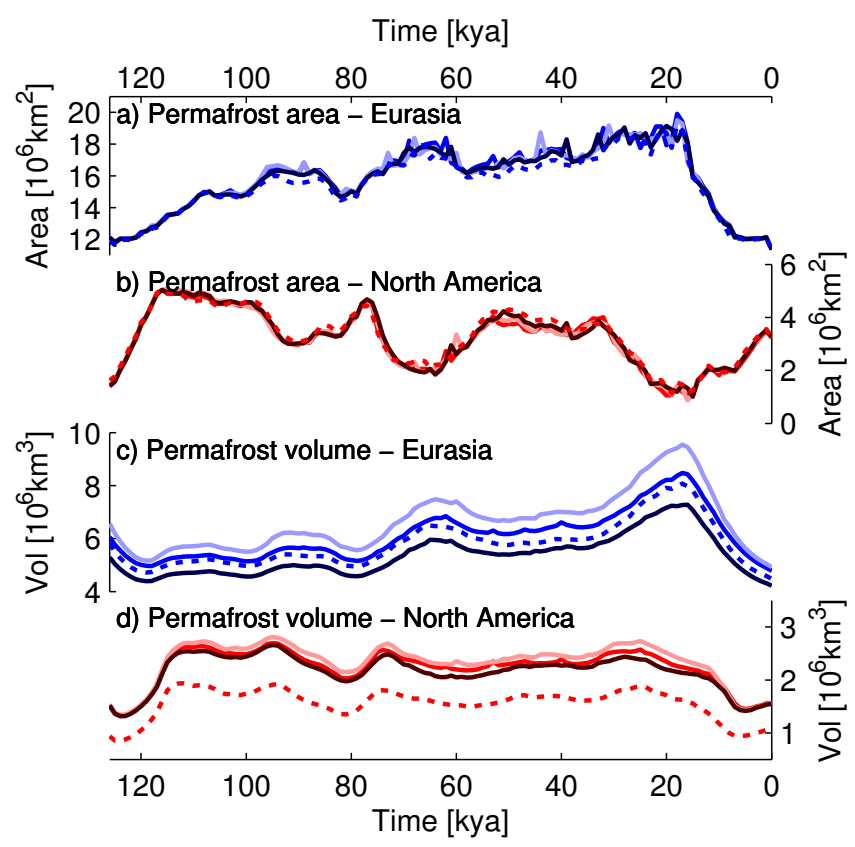

Figure 10. Evolution of permafrost area and permafrost volume over the last glacial cycle. Eurasian (a) and North American (b) permafrost area excluding ice-covered grid cells. Eurasian (c) and North American (d) permafrost volume. Solid lines represent simulations with surface porosity of $0.25,0.5$ and 0.75 (from light to dark) and the dotted lines are from the model run with the geothermal heat flux from Davies (2013).

mafrost increases this value to approximately 21.5 million square kilometers.

The area of permafrost not covered by ice sheets is relatively independent of porosity and geothermal heat flux, while the permafrost volume strongly depends on these parameters (Fig. 10). Permafrost area is insensitive to these parameters because it is determined mainly by the energy balance at the surface. On the other hand, permafrost volume is strongly affected by sediment porosity over Eurasia and by geothermal heat flux over North America, as already shown in the sensitivity analysis above (Fig. 7a and f).

Permafrost area and thickness at LGM, which is close to the time of maximum areal extent of Eurasian permafrost, are shown in Fig. 11. Over Eurasia permafrost is generally thicker than in the present day and extends almost as far south as $50^{\circ} \mathrm{N}$ over Europe and southwestern Russia. This is close to the estimates given by Vandenberghe et al. (2012), although they support an expansion of permafrost even further south over Europe. However, the estimates of Vandenberghe et al. (2012) include also discontinuous permafrost. The modeled permafrost extent is in even better agreement with the continuous permafrost extent estimates in Vandenberghe et al. (2014). Over North America, permafrost is simulated south of the LIS mainly over the Rocky Mountains, in very close agreement with reconstructions (Vanden-

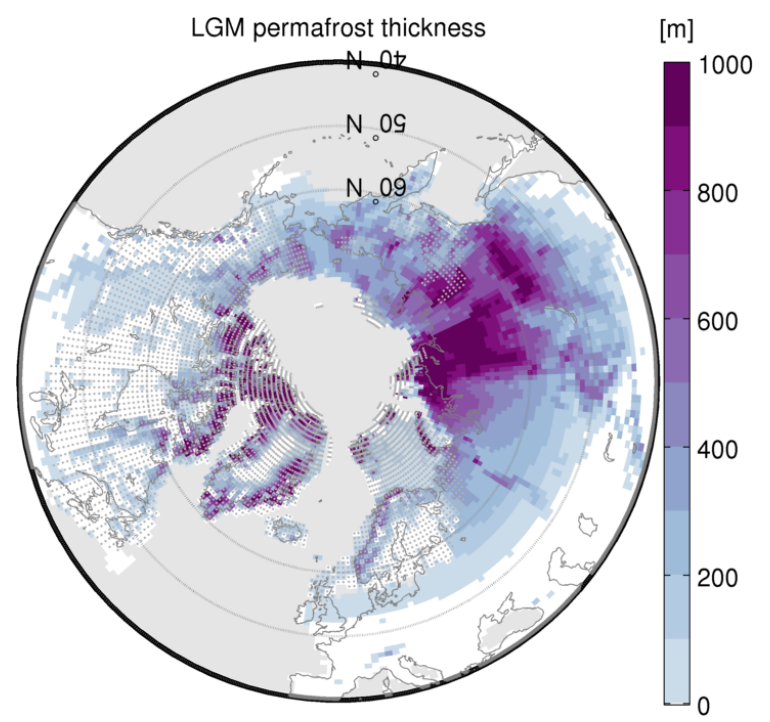

Figure 11. Modeled permafrost thickness at LGM, corresponding to the time of maximum areal extent of permafrost over Eurasia. Grey dots show grid cells covered by ice sheets.

berghe et al., 2014) and PMIP3 ensemble model estimates for the LGM (Saito et al., 2013). At LGM the modeled permafrost area is around 21 million square kilometers, lower than the mode of PMIP3 models, 29.5 million square kilometers (Saito et al., 2013), but within the PMIP3 ensemble range (20-37 million square kilometers). Some differences are probably due to the underestimation of permafrost extent over Europe and larger ice sheet in Siberia than prescribed in CMIP3 (Fig. 11).

White areas below the ice sheets in Fig. 11 indicate that no permafrost is present: more than half of the water is unfrozen at all levels below the ice. Large parts of the LIS, central Greenland and southeastern Scandinavia are free of permafrost in the reference model run.

Figures $12-15$ give a more detailed representation of the ground temperature and ice thickness evolution over the last glacial cycle at four selected locations. Over central Siberia permafrost is $600-700 \mathrm{~m}$ thick and remains relatively stable during the last glacial cycle although the temperature of the top of the permafrost layer changes through time as a response to surface temperature variations (Fig. 12).

In western Siberia permafrost is generally thinner, and permafrost thickness is therefore more sensitive to surface temperature variations (Fig. 13). Permafrost reaches a maximum thickness of $300 \mathrm{~m}$ around LGM and decreases to about $100 \mathrm{~m}$ in the present day. During the last centuries permafrost has also started to melt from above (Fig. 13b) because of the temperature increase associated with anthropogenic forcing.

At the same latitude over North America permafrost behaves radically different (Fig. 14). While Siberia is largely ice-free during the whole glacial cycle, large parts of Canada are ice-covered during glacial times. Before the ice sheet 


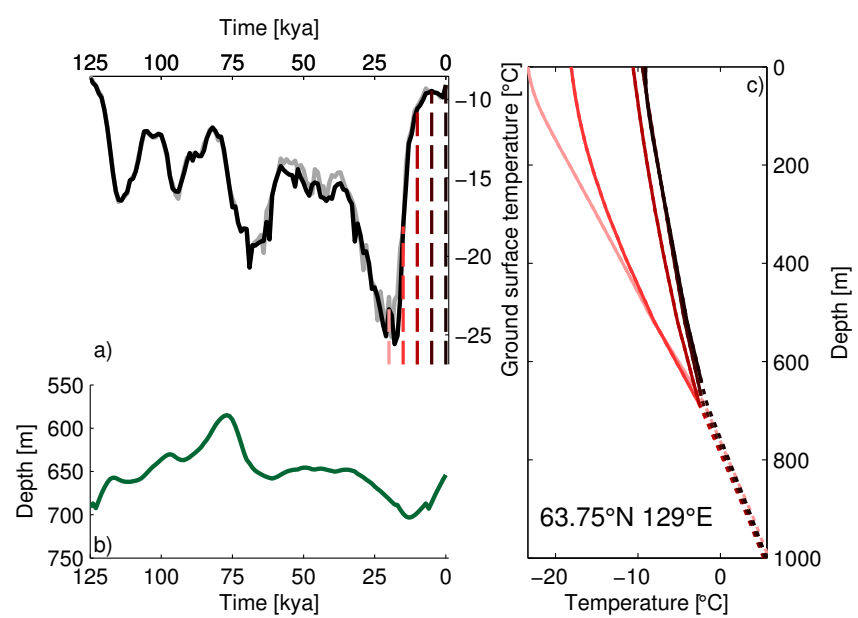

Figure 12. Evolution of ground surface temperature and ice thickness (a), base of permafrost layer (b) and ground temperature profiles since LGM (c) in central Siberia at the location with coordinates indicated in (c). In (a) the ground surface temperature (solid black line) evolution over the last glacial cycle is shown. The surface temperature (grey) evolution in the simulations with zero porosity is also shown for comparison. The red vertical lines indicate the times at which the ground temperature profiles are plotted in (c). In (b) the evolution of the depth of the base of the permafrost layer is presented (dark green). (c) shows the ground temperature profiles at selected times since the LGM as indicated in (a). Solid lines represent permafrost while dotted lines indicate no permafrost. The color code of the red lines in (a) and (c) corresponds to each other.

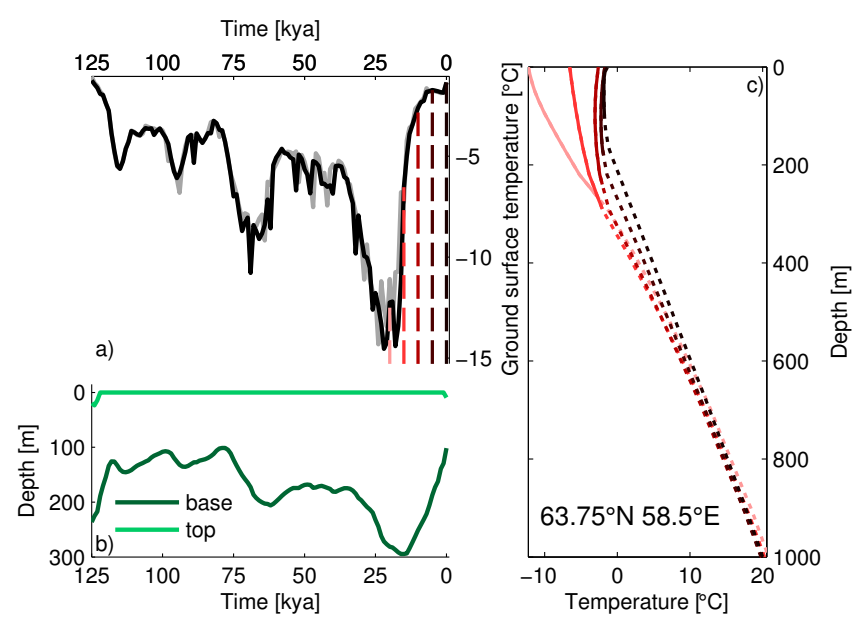

Figure 13. Same as Fig. 12 but for west Siberia. In (b) the evolution of the depth of the top (light green) of the permafrost layer is also shown.

starts to grow, surface temperature rapidly decreases from the Eemian to about $105 \mathrm{ka}$, and a $600 \mathrm{~m}$ thick layer of permafrost is formed. As soon as the ice starts to insulate the ground from the cold surface air temperatures, ground surface temperatures below the ice start to increase and

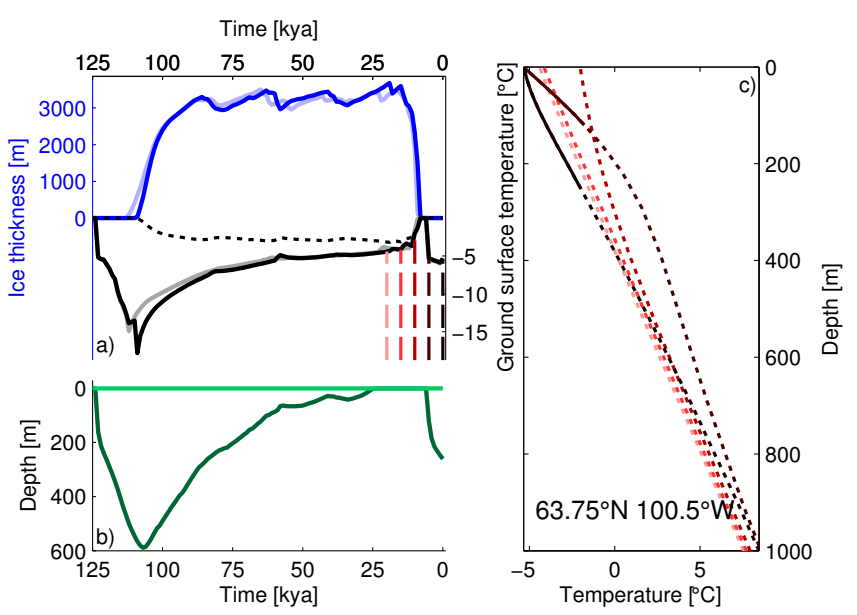

Figure 14. Same as Fig. 13 but for northern Canada. In (a) the ice thickness (dark blue) and the ground surface melting point temperature $T_{\mathrm{m}}$ (dotted black) evolution over the last glacial cycle are additionally shown. Ice thickness for the simulations with zero porosity (light blue) is also shown.
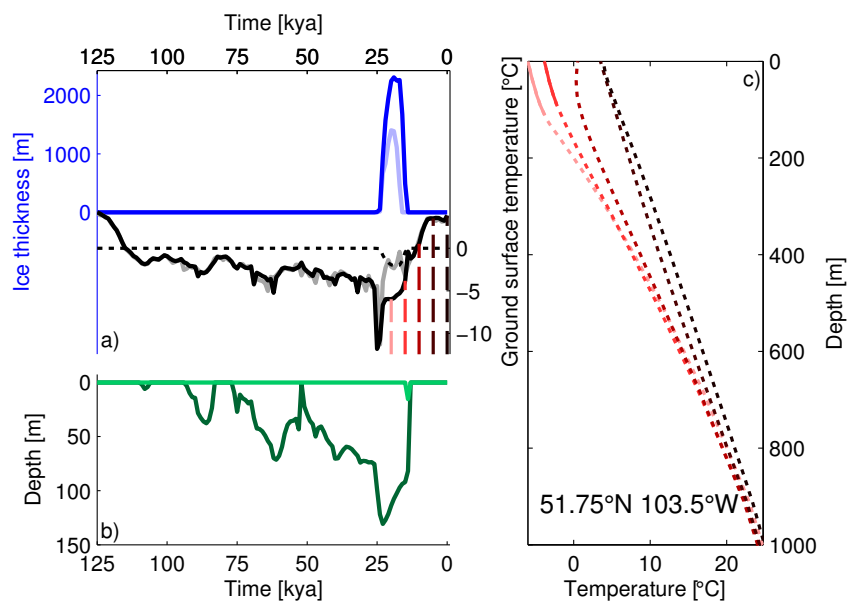

Figure 15. Same as Fig. 14 but for the southern flank of the Laurentide ice sheet.

permafrost to thaw from below. As soon as the ice base reaches melting point, after the LGM, ice thickness rapidly decreases. The melting ice sheet leaves behind a periglacial lake which enforces the top ground temperature to be $0{ }^{\circ} \mathrm{C}$, the assumed temperature of lake or ocean water. After the lake fades, the surface is again exposed to the relatively cold surface air temperatures and a permafrost layer begins to form again during the Holocene (Fig. 14). The part of Canada including this particular grid cell is free of sediments, and the small differences in temperature and ice thickness between simulations with zero and nonzero porosity shown in Fig. 14a therefore have to be entirely attributed to nonlocal effects.

A site further south (around $50^{\circ} \mathrm{N}$, where a thick sediment layer is present) remains ice free up to LGM. There, a 50- 


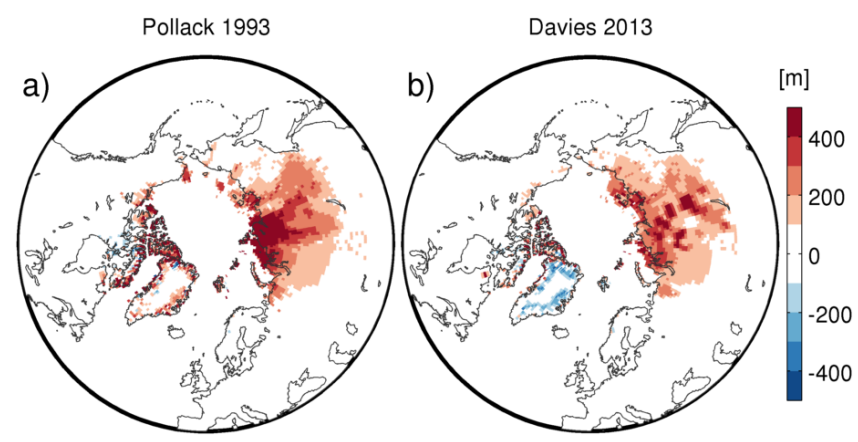

Figure 16. Present-day permafrost disequilibrium for the two model runs with different geothermal heat fluxes: (a) Pollack et al. (1993) and (b) Davies (2013). The equilibrium permafrost thickness is computed numerically as outlined in Appendix B, and the actual permafrost thickness is from the transient model simulations of the last eight glacial cycles.

$100 \mathrm{~m}$ permafrost layer forms during cold periods and completely melts during warmer periods (Fig. 15). Thick ice is modeled at this location around LGM, and it is interesting to note how the ice grows thicker and melts later when permafrost is included in the model (Fig. 15a). This explains the overall higher ice volume at LGM in the experiments including permafrost (Fig. 8a).

\subsection{Disequilibrium and convergence of permafrost thickness}

The evolution of the 3-D ground temperature field introduces a very long timescale into the climate-ice-sheet system. Presently, ground temperature and therefore permafrost thickness are far from equilibrium over some regions (Fig. 16). In particular over parts of Siberia present permafrost is up to $500 \mathrm{~m}$ thicker than it would be at equilibrium with preindustrial climate. When the geothermal heat flux from Pollack et al. (1993) is used, a large disequilibrium is evident also over the Arctic Archipelago (Fig. 16a). Permafrost thickness at these locations must therefore carry the information of long-term past temperature variations.

Starting from the temperature profile in equilibrium with present-day ground surface temperature given by Eq. (B2), it takes at least several glacial cycles for the Eurasian and North American permafrost volume to lose their dependence on the initial conditions (Fig. 17). A slow convergence with a timescale longer than $100 \mathrm{kyr}$ for permafrost thickness has been already shown by Osterkamp and Gosink (1991) for a deep permafrost site in Alaska using idealized surface temperature forcing over the past three glacial cycles. The present-day permafrost thickness simulated starting during different past interglacials shows a particularly slow convergence over some deep permafrost regions (Fig. 18). In Siberia, the difference in permafrost thickness between simulations started at 240 and $126 \mathrm{ka}$ is as large as $50 \mathrm{~m}$ (Fig. 18a).
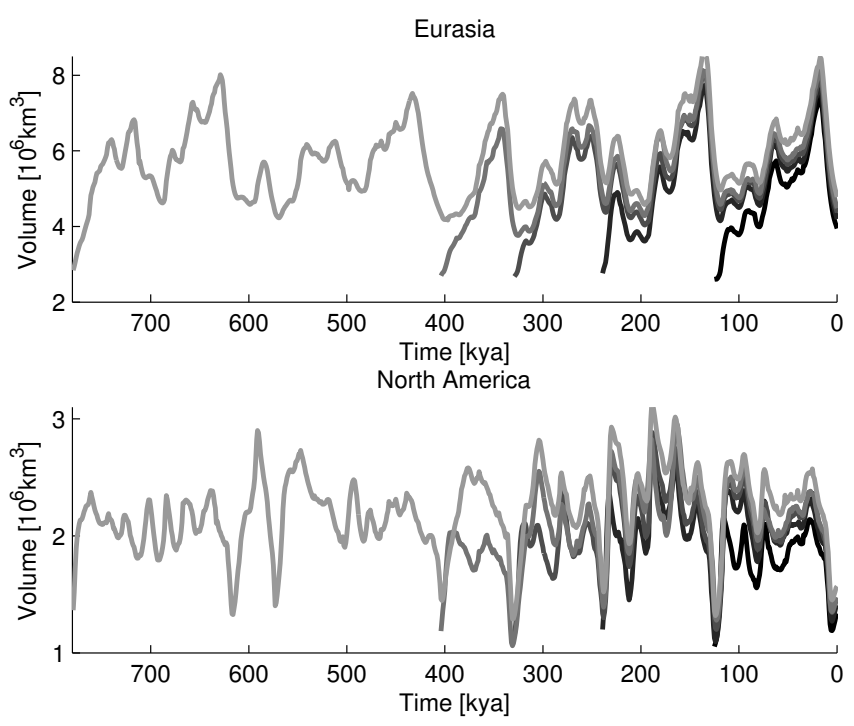

Figure 17. Permafrost volume evolution in simulations initialized with the same initial conditions but started at interglacial periods progressively further back in time. Top: Eurasia; bottom: North America.

This value drops to around $10 \mathrm{~m}$ when simulations started at 405 and $330 \mathrm{ka}$ are considered (Fig. 18c) but shows still notable differences even between experiments initiated at 780 and $405 \mathrm{ka}$ (Fig. 18d).

The slow convergence of permafrost thickness in some regions highlights the importance of proper initialization when considering permafrost evolution. Starting from equilibrium conditions at LGM or the Eemian as was done in previous studies (Kitover et al., 2013; Tarasov and Peltier, 2007) can thus lead to biased estimates of transient and present-day permafrost thickness.

\section{Conclusions}

In this study a permafrost module has been included in the climate-ice-sheet model CLIMBER-2. The model is shown to perform reasonably well at reproducing present-day permafrost extent and thickness. Modeled permafrost thickness is sensitive to the choice of some parameter values, in particular ground porosity and thermal conductivity of sediments and rock. Using different global data sets of geothermal heat flux also has a strong impact on simulated permafrost thickness. A realistic spatial distribution of geothermal heat flux and ground properties is therefore important for an accurate site-level simulation of ground temperature profiles and permafrost, as was already shown in Tarasov and Peltier (2007).

Permafrost extent at LGM agrees well with reconstructions and previous modeling estimates showing a southward expansion of permafrost down to almost $50^{\circ} \mathrm{N}$ over Europe and southeastern Russia, while permafrost is only locally 

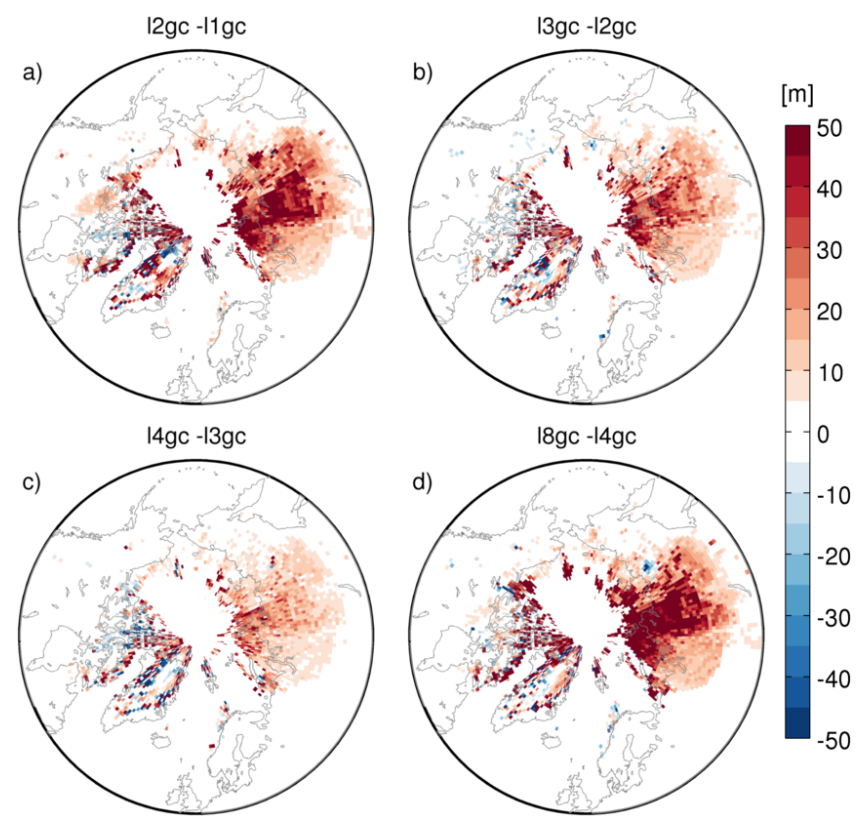

Figure 18. Present-day permafrost thickness differences between model runs started during different interglacial periods as indicated over each panel.

present south of the margin of the Laurentide ice sheet (Saito et al., 2013; Vandenberghe et al., 2012).

Present-day permafrost thickness is found to be far from equilibrium over deep permafrost regions of central Siberia and the Arctic Archipelago, where permafrost is presently up to $200-500 \mathrm{~m}$ thicker than it would be at equilibrium. In the deep permafrost areas, present-day permafrost depth strongly depends on the past climate history. Simulations initialized with the ground temperature profile in presentday equilibrium but started during different past interglacials show a very slow convergence of permafrost thickness. This implies that deep permafrost has a memory of surface temperature variations going back to at least $\approx 800 \mathrm{ka}$, the initialization time of the longest transient simulation performed. Thus, present permafrost estimates from models initialized at equilibrium during the Eemian (e.g., Tarasov and Peltier, 2007) or LGM (e.g., Kitover et al., 2013) will be biased.
Over the last glacial cycle permafrost has a relatively modest impact on simulated $\mathrm{NH}$ ice sheet volume, except at LGM, when including permafrost increases ice volume by about $15 \mathrm{~m}$ sea level equivalent. However, the effect of permafrost on ice sheet volume is expected to depend on the amount of warm-based ice sheet simulated during the glacial cycle, which is known to be model-dependent. Independent model simulations are therefore required to confirm the robustness of this result. In our model the increased ice volume at LGM is explained by a delayed melting of the ice sheet base from below where the ice sheet is above a thick sediment layer. In this case the geothermal heat flux is first used to melt the permafrost layer below the ice before the ice base can reach the melting point. Permafrost affects ice sheet dynamics only when ice extends over areas covered by thick sediments, which is the case, e.g., at LGM. It is therefore argued that permafrost could have played a role for ice sheet evolution in the Early Pleistocene, when all continents were covered by a thick sediment layer. Additional model simulations will be required to confirm the importance of permafrost for the Early Pleistocene glacial cycles. 


\section{Appendix A: Permafrost model}

The contribution from phase changes in Eq. (1) can be written as (accounting also for possible changes in time of the melting point temperature $T_{\mathrm{m}}$ )

$L \rho_{\mathrm{w}} \frac{\partial \theta_{\mathrm{w}}}{\partial t}=L \rho_{\mathrm{w}} \phi\left(\frac{\partial f_{\mathrm{w}}}{\partial T} \frac{\partial T}{\partial t}+\frac{\partial f_{\mathrm{w}}}{\partial T_{\mathrm{m}}} \frac{\partial T_{\mathrm{m}}}{\partial t}\right)$,

with

$\frac{\partial f_{\mathrm{w}}}{\partial T}= \begin{cases}-2 \frac{T-T_{\mathrm{m}}}{\Delta T_{\mathrm{w} / \mathrm{i}}^{2}} e^{-\left(\frac{T-T_{\mathrm{m}}}{\Delta T_{\mathrm{w} / \mathrm{i}}}\right)^{2}} & T<T_{\mathrm{m}} \\ 0 & T \geq T_{\mathrm{m}},\end{cases}$

$\frac{\partial f_{\mathrm{w}}}{\partial T_{\mathrm{m}}}= \begin{cases}2 \frac{T-T_{\mathrm{m}}}{\Delta T_{\mathrm{w} / \mathrm{i}}^{2}} e^{-\left(\frac{T-T_{\mathrm{m}}}{\Delta T_{\mathrm{w} / \mathrm{i}}}\right)^{2}} & T<T_{\mathrm{m}} \\ 0 & T \geq T_{\mathrm{m}} .\end{cases}$

The first term in Eq. (A1) can be formally viewed as contributing to an increase in heat capacity, and Eq. (1) can be rewritten as

$$
\begin{aligned}
& \left(\rho C+L \rho_{\mathrm{w}} \phi \frac{\partial f_{\mathrm{w}}}{\partial T}\right) \frac{\partial T}{\partial t}=\frac{\partial}{\partial z}\left(k \frac{\partial T}{\partial z}\right) \\
& -L \rho_{\mathrm{w}} \phi \frac{\partial f_{\mathrm{w}}}{\partial T_{\mathrm{m}}} \frac{\partial T_{\mathrm{m}}}{\partial t} .
\end{aligned}
$$

The last term in Eqs. (A1) and (A4) accounts for the energy needed or released during phase changes associated with a shift in $T_{\mathrm{m}}$ due to locally changing ice sheet thickness and is usually small.

\section{Appendix B: Equilibrium ground temperature profiles}

The ground temperature profile at equilibrium can be derived by setting the time derivative terms in Eq. (1) to 0. This results in

$\frac{\partial}{\partial z}\left(k(z) \frac{\partial T}{\partial z}\right)=0$,

or

$k(z) \frac{\partial T}{\partial z}=$ constant.

The boundary conditions read

TOP: $T(z=0)=$ MAGST,

BOT: $\left.\frac{\partial T}{\partial z}\right|_{z=z_{\mathrm{b}}}=-\frac{q_{\mathrm{geo}}}{\left.k\right|_{z=z_{\mathrm{b}}}}, z_{\mathrm{b}}=-5000 \mathrm{~m}$.

If $k$ is uniform, Eq. (B2) can be simply integrated to give a linear temperature profile:

$T(z)=\operatorname{MAGST}+\frac{q_{\mathrm{geo}}}{k} z$.

If $k$ is depth-dependent following Eq. (8),

$k(z)=k_{\mathrm{s}}^{1-\phi(z)} k_{\mathrm{w}}^{\theta_{\mathrm{w}}(z)} k_{\mathrm{i}}^{\phi(z)-\theta_{\mathrm{w}}(z)}$,

with

$\theta_{\mathrm{w}}(z)=\phi(z) e^{-\left(\frac{T(z)-T_{\mathrm{m}}(z)}{\Delta T_{\mathrm{w} / \mathrm{i}}}\right)^{2}}$.

Equation (B2) can be solved numerically using the boundary conditions. 
Acknowledgements. M. Willeit acknowledges support by the German Science Foundation DFG grant GA 1202/2-1.

Edited by: V. Rath

\section{References}

Athy, L. F.: Density, porosity, and compaction of sedimentary rocks, AAPG Bull., 14, 1-24, 1930.

Bauder, A., Mickelson, D. M., and Marshall, S. J.: Numerical modeling investigations of the subglacial conditions of the southern Laurentide ice sheet, Ann. Glaciol., 40, 219-224, 2005.

Brovkin, V., Ganopolski, A., and Svirezhev, Y.: A continuous climate-vegetation classification for use in climate-biosphere studies, Ecol. Model., 101, 251-261, 1997.

Brovkin, V., Bendtsen, J. R., Claussen, M., Ganopolski, A., Kubatzki, C., Petoukhov, V., and Andreev, A.: Carbon cycle, vegetation, and climate dynamics in the Holocene: experiments with the CLIMBER-2 model, Global Biogeochem. Cy., 16, 86-1-8620, 2002.

Brown, J., Ferrians, O., Heginbottom, J. A., and Melnikov, E.: Circum-Arctic Map of Permafrost and Ground-Ice Conditions, available at: http://nsidc.org/data/ggd318.html (last access: 10 January 2015), 2014.

Burn, C. and Smith, C.: Observations of the "thermal offset" in nearsurface mean annual ground temperatures at several sites near Mayo, Yukon Territory, Canada, Arctic, 41, 99-104, 1988.

Calov, R., Ganopolski, A., Claussen, M., Petoukhov, V., and Greve, R.: Transient simulation of the last glacial inception. Part I: glacial inception as a bifurcation in the climate system, Clim. Dynam., 24, 545-561, 2005.

Carslaw, H. S. and Jaeger, J. C.: Heat in Solids, vol. 19591, Clarendon Press, Oxford, 1959.

Clark, P. U. and Pollard, D.: Origin of the Middle Pleistocene Transition by ice sheet erosion of regolith, Paleoceanography, 13,19, 1998.

Crichton, K. A., Roche, D. M., Krinner, G., and Chappellaz, J.: A simplified permafrost-carbon model for long-term climate studies with the CLIMBER-2 coupled earth system model, Geosci. Model Dev., 7, 3111-3134, doi:10.5194/gmd-7-31112014, 2014.

Davies, J. H.: Global map of Solid Earth surface heat flow, Geochem. Geophy. Geosy., 14, 4608-4622, 2013.

Dutra, E., Balsamo, G., Viterbo, P., Miranda, P. M. A., Beljaars, A., Schär, C., and Elder, K.: An improved snow scheme for the ECMWF land surface model: description and offline validation, J. Hydrometeorol., 11, 899-916, 2010.

Farouki, O. T.: Thermal properties of soils, Special Report 81-1, Cold Regions Research and Engineering Laboratory (CRREL), Hanover, NH, 1981.

Galushkin, Y.: Numerical simulation of permafrost evolution as a part of sedimentary basin modeling: permafrost in the PlioceneHolocene climate history of the Urengoy field in the West Siberian basin, Can. J. Earth Sci., 34, 935-948, 1997.

Ganopolski, A. and Calov, R.: The role of orbital forcing, carbon dioxide and regolith in $100 \mathrm{kyr}$ glacial cycles, Clim. Past, 7, 1415-1425, doi:10.5194/cp-7-1415-2011, 2011.

Ganopolski, A., Petoukhov, V., Rahmstorf, S., Brovkin, V., Claussen, M., Eliseev, A., and Kubatzki, C.: CLIMBER-2: a cli- mate system model of intermediate complexity, Part II: model sensitivity, Climate Dynamic, 17, 735-751, 2001.

Ganopolski, A., Calov, R., and Claussen, M.: Simulation of the last glacial cycle with a coupled climate ice-sheet model of intermediate complexity, Clim. Past, 6, 229-244, doi:10.5194/cp-6-2292010, 2010.

Greve, R.: Application of a polythermal three-dimensional ice sheet model to the Greenland ice sheet: response to steady-state and transient climate scenarios, J. Climate, 10, 901-918, 1997.

Hardy and Associates Ltd.: Study of well logs in the Arctic Islands to outline permafrost thickness and/or gas hydrate occurrence, Open file 84-8, EMR Canada, Earth Physics Branch, 1984.

Hillel, D.: Applications of Soil Physics, Elsevier, Academic Press, New York, New York, 1980.

Hooke, R. L.: Principles of Glacier Mechanics, Cambridge University Press, Cambridge, UK, 2005.

Huybrechts, P.: Sea-level changes at the LGM from ice-dynamic reconstructions of the Greenland and Antarctic ice sheets during the glacial cycles, Quaternary Sci. Rev., 21, 203-231, 2002.

International Permafrost Association: IPA-IPY Thermal State of Permafrost (TSP) Snapshot Borehole Inventory, National Snow and Ice Data Center, Boulder, Colorado USA, doi:10.7265/N57D2S25, 2010.

Kitover, D. C., van Balen, R. T., Roche, D. M., Vandenberghe, J., and Renssen, H.: New estimates of permafrost evolution during the last $21 \mathrm{k}$ years in Eurasia using numerical modelling, Permafrost Periglac., 24, 286-303, 2013.

Kitover, D. C., van Balen, R., Roche, D. M., Vandenberghe, J., and Renssen, H.: Advancement toward coupling of the VAMPER permafrost model within the Earth system model iLOVECLIM (version 1.0): description and validation, Geosci. Model Dev., 8, 144-1460, doi:10.5194/gmd-8-1445-2015, 2015.

Kominz, M. A., Patterson, K., and Odette, D.: Lithology dependence of porosity in slope and deep marine sediments, J. Sediment. Res., 81, 730-742, 2011.

Laskar, J., Robutel, P., Joutel, F., Gastineau, M., Correia, A. C. M., and Levrard, B.: A long-term numerical solution for the insolation quantities of the Earth, Astron. Astrophys., 428, 261-285, 2004.

Laske, G. and Masters, G. A.: Global digital map of sediment thickness, EOS T. Am. Geophys. Un., 78, F483, igppweb.ucsd.edu/ $\sim$ gabi/sediment.html, 1997.

Lunardini, V.: Freezing of soil with an unfrozen water content and variable thermal properties, CRREL Report 88-2, 1988.

Lunardini, V.: Permafrost formation time, CRREL Report 95-8, 1995.

Marshall, S. J. and Clark, P. U.: Basal temperature evolution of North American ice sheets and implications for the 100-kyr cycle, Geophys. Res. Lett., 29, 2214, doi:10.1029/2002GL015192, 2002.

Melanson, A., Bell, T., and Tarasov, L.: Numerical modelling of subglacial erosion and sediment transport and its application to the North American ice sheets over the Last Glacial cycle, Quaternary Sci. Rev., 68, 154-174, 2013.

Melnikov, E.: Catalog of boreholes from Russia and Mongolia, In: International Permafrost Association, Data and Information Working Group, comp. Circumpolar Active-Layer Permafrost System (CAPS), version 1.0. CD-ROM available from National 
Snow and Ice Data Center, nsidc@kryos.colorado.edu. Boulder, Colorado, NSIDC, 1998.

Mottaghy, D. and Rath, V.: Latent heat effects in subsurface heat transport modelling and their impact on palaeotemperature reconstructions, Geophys. J. Int., 164, 236-245, 2006.

Niu, G. and Yang, Z.: Effects of frozen soil on snowmelt runoff and soil water storage at a continental scale, J. Hydrometeorol., 7, 937-952, 2006.

Osterkamp, T. E. and Gosink, J. P.: Variations in permafrost thickness in response to changes in paleoclimate, J. Geophys. Res., 96, 4423, doi:10.1029/90JB02492, 1991.

Petoukhov, V., Ganopolski, A., Brovkin, V., Claussen, M., Eliseev, A., Kubatzki, C., and Rahmstorf, S.: CLIMBER-2: a climate system model of intermediate complexity. Part I: model description and performance for present climate, Clim. Dynam., 16, 1-17, 2000.

Pollack, H. N., Hurter, S. J., and Johnson, J. R.: Heat flow from the Earth's interior: Analysis of the global data set, Rev. Geophys., 31, 267-280, 1993.

Romanovsky, V. E. and Osterkamp, T. E.: Interannual variations of the thermal regime of the active layer and near-surface permafrost in northern Alaska, Permafrost Periglac., 6, 313-335, 1995.

Romanovsky, V. E., Smith, S. L., and Christiansen, H. H.: Permafrost thermal state in the polar Northern Hemisphere during the international polar year 2007-2009: a synthesis, Permafrost Periglac., 21, 106-116, 2010.

Saito, K., Sueyoshi, T., Marchenko, S., Romanovsky, V., OttoBliesner, B., Walsh, J., Bigelow, N., Hendricks, A., and Yoshikawa, K.: LGM permafrost distribution: how well can the latest PMIP multi-model ensembles perform reconstruction?, Clim. Past, 9, 1697-1714, doi:10.5194/cp-9-1697-2013, 2013.
Smith, M. W. and Riseborough, D. W.: Climate and the limits of permafrost: a zonal analysis, Permafrost Periglac., 13, 1-15, 2002.

Smith, S. and Burgess, M.: A digital database of permafrost thickness in Canada, available at: http://nsidc.org/data/ggd620.html (last access: 10 January 2015), 2004.

Stewart, J.: Modelling surface conductance of pine forest, Agr. Forest Meteorol., 43, 19-35, 1988.

Tarasov, L. and Peltier, W. R.: Coevolution of continental ice cover and permafrost extent over the last glacial-interglacial cycle in North America, J. Geophys. Res., 112, F02S08, doi:10.1029/2006JF000661, 2007.

Vandenberghe, J., Renssen, H., Roche, D., Goosse, H., Velichko, A., Gorbunov, A., and Levavasseur, G.: Eurasian permafrost instability constrained by reduced sea-ice cover, Quaternary Sci. Rev., 34, 16-23, 2012.

Vandenberghe, J., French, H. M., Gorbunov, A., Marchenko, S., Velichko, A., Jin, H., Cui, Z., Zhang, T., and Wan, X.: The Last Permafrost Maximum (LPM) map of the Northern Hemisphere: permafrost extent and mean annual air temperatures, 25-17 ka BP, Boreas, 43, 652-666, 2014.

Verseghy, D.: CLASS-A Canadian land surface scheme for GCMs. I. Soil model, Int. J. Climatol., 11, 111-133, 1991.

Waelbroeck, C., Labeyrie, L., Michel, E., Duplessy, J., McManus, J., Lambeck, K., Balbon, E., and Labracherie, M.: Sealevel and deep water temperature changes derived from benthic foraminifera isotopic records, Quaternary Sci. Rev., 21, 295-305, 2002.

Watanabe, K. and Mizoguchi, M.: Amount of unfrozen water in frozen porous media saturated with solution, Cold Reg. Sci. Technol., 34, 103-110, 2002.

Williams, P. and Smith, M.: The Frozen Earth: Fundamentals of Geocryology, Cambridge University Press, Cambridge, 1989. 